\title{
Faulquemont - Créhange - Pontpierre
}

RD 910, déviation de Faulquemont, tranche 2

\section{Xavier Antoine}

\section{(2) OpenEdition}

\section{Journals}

Édition électronique

URL : http://journals.openedition.org/adlfi/9127

ISSN : 2114-0502

Éditeur

Ministère de la culture

Référence électronique

Xavier Antoine, «Faulquemont - Créhange - Pontpierre », ADLFI. Archéologie de la France - Informations

[En ligne], Lorraine, mis en ligne le 01 mars 2001, consulté le 20 avril 2019. URL : http://

journals.openedition.org/adlfi/9127

Ce document a été généré automatiquement le 20 avril 2019.

(C) Ministère de la Culture et de la Communication, CNRS 


\section{Faulquemont - Créhange - Pontpierre}

RD 910, déviation de Faulquemont, tranche 2

\section{Xavier Antoine}

Identifiant de l'opération archéologique : F1357200100039A

Date de l'opération : 2001 (EV)

1 La déviation de Faulquemont, projetée dans le cadre du « réseau vert », comprend $8 \mathrm{~km}$ de tracé routier neuf. Lors des sondages menés en décembre 2000 dans la partie nord du tracé, au lieu-dit "Kelsborn», un secteur d'environ $6000 \mathrm{~m}^{2}$, recelant une nécropole à incinération et des bâtiments gallo-romains, a été mis au jour (voir Bilan scientifique régional 2000, p. 76).

2 La seconde tranche de sondages opérée en mars 2001, a révélé la présence de deux nouveaux sites archéologiques. Il s'agit d'une part, d'une nécropole à incinération galloromaine localisée sur la commune de Pontpierre, au lieu-dit «Almert», sur environ $1900 \mathrm{~m}^{2}$ et, d'autre part, d'un habitat en matériaux légers attribuable en première analyse à la période gallo-romaine situé au lieu-dit « Nahtetzel » et qui s'étend sur une superficie comprise entre $6000 \mathrm{~m}^{2}$ et $10000 \mathrm{~m}^{2}$. 
INDEX

Index géographique : Lorraine, Moselle (57), Faulquemont

Index chronologique : Empire romain

Thèmes : habitat, nécropole à incinération

operation Fouille d'évaluation (EV)

\section{AUTEURS}

\section{XAVIER ANTOINE}

